\title{
Henkilöstön suosimat työssä oppimisen muodot
}

\author{
Eeva Hörkkö, Heikki Silvennoinen \& Tero Järvinen
}

\section{ABSTRACT \\ Personnel's preferred ways of workplace learning}

The aim of the study is to analyze different ways of workplace learning, particularly the connections between workplace learning and one's gender, age and organizational hierarchy position. The survey conducted among the Finnish water utilities' personnel $(\mathrm{N}=412)$ draws on three metaphors of learning, namely acquisition, participation and knowledge-creation. According to the results, knowledge acquisition and knowledge creation are predicted by organizational hierarchy position and learning by participation is predicted by gender and age. The results give an idea what kind of ways of learning and learning environments could be designed in workplaces when taking into account the needs and preferences of employees in different organizational positions.

Keywords: workplace learning, gender, age, organizational hierarchy, acquisition, predicted by participation and knowledge-creation metaphor

\section{JOHDANTO}

Henkilöstövoimavarojen hallinnointi esimerkiksi työilmapiiristä huolehtimalla ja työntekijöiden osaamista kehittämällä on entistä tärkeämpi osa yritysten ja julkisorganisaatioiden strategiaa kilpailukyvyn ja tuloksellisuuden parantamiseksi. Palkansaajille tarjotut mahdollisuudet kehittyä ja toteuttaa itseään vaikuttavat myös yrityksen maineeseen ja julkikuvaan. Keskimäärin oppimismahdollisuudet ovat suomalaisessa työelämässä hyvät. Vuosittain puhelinhaastatteluna toteutettavan työolobarometrin mukaan neljä palkansaajaa viidestä katsoo, että työssä voi oppia jatkuvasti uusia asioita. Myös henkilöstökoulutukseen osallistuminen on Suomessa kansainvälisesti korkealla tasolla: puolet palkansaajista, noin miljoona suomalaista osallistuu vuosittain työnantajan kustantamaan koulutukseen. (Cedefop 2015; Lyly-Yrjänäinen 2018; OECD 2005; 2017.)

Keskimääräiset luvut ovat käyttökelpoisia kansainvälisissä vertailuissa, mutta niin oppimismahdollisuuksiin kuin henkilöstökoulutukseen osallistumiseenkin sisältyy runsaasti organisaatioaseman, toimialan, iän ja sukupuolen mukaista vaihtelua. Asema organisaation hierarkiassa on tutkimusten mukaan tärkein yksittäinen oppimismahdollisuuksia määrittävä tekijä (ks. Cedefop 2015; Harteis ym. 2015). Vaikka henkilöstökoulutukseen osallistuminen on viime vuosikymmenten aikana yleistynyt Suomessa kaikissa sosioekonomisissa ryhmissä, suhteelliset erot työntekijöiden ja toimihenkilöiden välillä ovat pysyneet sitkeästi lähes entisellään. (Cedefop 2015; Eurostat 2018; Rinne ym. 1995; Silvennoinen \& Lindberg 2016.)

Suomessa työnantajan halukkuutta kouluttaa henkilöstöään voidaan iän mukaisessa tarkastelussa kuvata käänteisenä u-käyränä. Työnantajat kouluttavat aktiivisimmin keski-ikäistä henkilöstöään. Henkilöstökoulutukseen osallistumisaste kääntyy laskuun työntekijän lähestyessä viidettäkymmenettä ikävuottaan. Iän ja sosioekonomisen aseman yhdysvaikutus näkyy erityisesti alemmissa sosiaaliryhmissä: kun ikää karttuu, kiinnostus vähenee (Cedefop 2015; Taylor 2010, 264; Warr \& Birdi 1998, 200). Oppimisasenteissa ei ole siis kysymys vain iästä, vaan myös työn luonteesta ja yksilön koulutushistoriasta. Mutta näyttää myös siltä, ettei osaamisen kehittämiseen vanhemmalla iällä ole työpaikoilla riittävästi kannustimia, eivätkä koulutuskäytännöt ehkä vastaa kaikille ikääntyville sopivia oppimistapoja. 
Aikuiskoulutustutkimukset ovat toistuvasti osoittaneet naisten suhtautuvan miehiä myönteisemmin oppimiseen ja kouluttautumiseen aikuisiällä (Naumanen 1994; 2002). Sukupuolen mukaiset erot näkyvät siten, että Suomessa naisten osallistuminen henkilöstökoulutukseen on miehiä yleisempää lähes kaikissa ikäryhmissä, mikä ei ole kansainvälisesti vertaillen aivan tavallista (Cedefop 2015; Silvennoinen \& Nori 2012).

Kehittyvän teknologian vuoksi työntekijöiden osaamisvaatimukset muuttuvat kaiken aikaa, eikä uuden tekniikan käyttöönotto suju ongelmitta. Työpaikoilla uudistuksia tehdään teknologia- ja järjestelmävetoisesti (Väyrynen ym. 2015, 323-324), ei niinkään ottamalla lähtökohdaksi työntekijöiden yksilölliset erityispiirteet ja niihin perustuvat tarpeet. Yksilöiden ja ryhmien väliset erot oppimistavoissa ja -toiveissa sekä oppimismahdollisuuksien hyödyntämisessä ovat työpaikoilla pulma niin henkilöstöhallinnolle ja koulutustoiminnalle kuin työn organisoinnillekin. Työllisyyden ja työnteon muuttuvien rakenteiden lisäksi työssä oppimisen uudenlaiselle organisoimiselle ja räätälöinnille luo painetta myös koulutusurien yksilöllistyminen. Suomessa eri ikäpolviin kuuluvien taidot ja osaaminen poikkeavat paljon toisistaan, kuten OECD:n kansainvälinen PIAACtutkimus osoitti (OECD 2013). Myös koulutusja osaamistarpeet ovat eriytyneet iän ja sosioekonomisen aseman mukaan. Toisaalta kun suuret ikäluokat siirtyvät pois työelämästä, heidän mukanaan katoaa työpaikoilta vuosikymmenten mittaan kasautunutta äänetöntä osaamista, ellei sitä osata jakaa nuoremmille työyhteisöjen oppimisjärjestelmillä.

Eriytyvien osaamistarpeiden vuoksi onkin tärkeää saada tietoa eri henkilöstöryhmille soveltuvista työssä oppimisen tavoista. Tässä artikkelissa analysoimme vesihuoltolaitoksilla kerätyn kyselyaineiston $(\mathrm{N}=412)$ avulla, millaiset työssä oppimisen tavat eri asemissa toimivat, eri-ikäiset miehet ja naiset kokevat itselleen sopiviksi. Artikkelin aluksi perehdytään tutkimuksen teoreettiseen viitekehykseen, johon aineiston analyysi ja tulosten tulkinta nojaavat. Tämän jälkeen esitellään aineisto, menetelmät ja aineiston analyysi. Lopuksi esitetään empiiriset tulokset sekä pohditaan niiden yleisempää merkitystä.
Ammatillisen koulutuksen siirtämistä yhä enemmän työpaikoille perustellaan paljolti sillä, että työelämän nopeutuvien muutosten vuoksi koulutuksen pitää pystyä entistä joustavammin tuottamaan työpaikkakohtaisia taitoja ja vastaamaan yksilökohtaisiin osaamistarpeisiin. Artikkelin tarkoitus onkin tuottaa tutkimustietoa henkilöstövoimavarojen hallinnan muotoiluun ja oppimismahdollisuuksien organisointiin sekä työelämän osaamisesta käytävään keskusteluun yleisemminkin.

\section{OPPIMINEN KÄYTÄNTÖYHTEISÖISSÄ}

Oppiminen tapahtuu aina jossakin ympäristössä, jonka luonnetta määrittävät niin materiaaliset kuin sosiaaliset ja kulttuuriset olot - fyysiset tilat, esineet, välineet, laitteet, tavat ja tottumukset sekä muut ihmiset ja sosiaaliset suhteet (Fenwick 2010, 84-85; Hakkarainen 2000; Hakkarainen \& Paavola 2008, 68). Koulutustutkimuksessakin fokus on laajentunut yksilöpsykologisista kognitiivisista prosesseista sosiaalisen oppimisen analyyseihin. Käsitys yksilöstä hankkimassa tietoja ja taitoja muusta elämästä eristetyissä oppilaitoksissa ja luokkahuoneissa on saanut antaa tilaa ymmärrykselle monenlaisissa ympäristöissä ja tilanteissa tapahtuvasta oppimisesta, joka perustuu osallistumiseen käytännön toimintaan yhdessä muiden kanssa.

Tämän artikkelin oppimiskäsitys perustuu sosiaalisen oppimisen teoriaan (social learning theory, Bandura 1977; 1997), joka tarkastelee ihmisen käyttäytymistä kognitiivisten tekijöiden, käyttäytymismallien ja ympäristön keskinäisessä vuorovaikutuksessa. Teoria pohjautuu paljossa Lev Vygotskyn (1978, 24-30, 84-91) käsitykseen oppimisesta luonnollisena osana ihmisen sosiaalista kehitystä (social development theory). Vygotsky korostaa yksilön psyykkisen toiminnan olevan pohjimmiltaan sosiaalisen ja historiallisen kontekstin muovaamaa (Wertsch 2010, 231). Samaan tapaan Jean Laven ja Etienne Wengerin (1991) luomassa ja Wengerin (1998) edelleen kehittelemässä käytäntöyhteisön (community of practice) viitekehyksessä oppiminen nähdään elimellisenä osana yhteisöjen toimintaan osallistumista.

Käytäntöyhteisö on ryhmä yhdessä työskenteleviä ihmisiä, jotka oppivat yhteiseen tekemiseen ja vuorovaikutukseen osallistumisen kaut- 
ta (Lave \& Wenger 1991; Wenger 1998). Käytäntöyhteisö ei viittaa mihin tahansa ryhmään, vaan pikemminkin se kuvastaa erityistä yhteisötason strukturoinnin prosessia. Käytäntöyhteisössä neuvotellaan siitä, mikä on kyseisen alan ydinosaamista ja mitä sen hallitseminen vaatii. Samalla neuvotteluprosessi strukturoi yhteisön sosiaalisia suhteita. 'Ala' viittaa siihen erityisalaan, jossa yhteisö väittää olevansa legitiimi määrittelemään alan osaamista sisältöineen ja pätevyyksineen. Kyseessä ei siis ole pelkästään tiimi, jolla on yhteinen tehtävä, vaan pikemminkin oppimisen - ja osaamisen hallinnan - kumppanuus yhdessä harjoitetulla erityisalalla. Käytäntöyhteisön jäsenet eivät ole ainoastaan verkostoituneita keskenään; yhteisössä korostuu identifioituminen alan yhteisesti neuvoteltuun osaamiseen (Farnsworth ym. 2016, 143-144).

Käytäntöyhteisö on aina valtasuhteiden kenttä, minkä vuoksi myös oppiminen ja yhteisössä arvostetun osaamisen määrittäminen ovat valtasuhteiden lävistämiä sosiaalisia prosesseja. Tyypillisesti yhteisö voi myös rakentaa yhteisöön sisäänpääsyä säänteleviä kriteereitä, jotka eivät perustu ainoastaan osaamiseen. Käytäntöyhteisöt ovat siis yhdentyyppisiä sosiaalisia sulkeumia (ks. Murphy 1988), joissa osallisuutta säädellään koulutustutkintojen lisäksi esimerkiksi sukupuolen ja iän sekä sosiaalisen, kulttuurisen ja etnisen taustan perusteella (esim. Roscigno ym. 2001). Työntekijä voi kokea esteet syvenevään osallistumiseen marginalisoimisena tai perifeerisyytenä suhteessa arvostetun osaamisen haltijoihin. Mikäli yksilö on vahvasti identifioitunut alaan ja yhteisön osaamiseen, koettu marginalisoituminen voi saada hänet hakeutumaan pois yhteisöstä. Usein tulokkaan marginaaliasema on kuitenkin vain väliaikainen tila ja muuttuu myöhemmin yhteisön jäsenyydeksi (Farnsworth ym. 2016, 145-146; Wenger 1998, 189-191).

Käytäntöyhteisöissä oppiminen ei rajoitu sisääntulovaiheeseen eikä konkretisoidu vain järjestettyinä koulutustilaisuuksina ja seminaareina. Ihmiset oppivat monin tavoin työtä tekemällä, useimmiten työyhteisössä työkavereiden kanssa. Vertaisilta oppimiseen (peer-learning) ja osaamisen jakamiseen työssä oppimisen muotoina on viime vuosina kiinnitetty tutkimuksissa huomiota enenevässä määrin (Boud \& Lee 2005; Boud \& Middleton 2003; Engeström 2001).
Työntekijät mitä erilaisimmilla työpaikoilla ovat mukana monenlaisten tietojen ja taitojen opettamisessa kollegoilleen. Toisten opettaminen, ohjaaminen ja neuvominen ovat osa työpaikan oppimisprosessia. Niin noviiseilla kuin kokeneillakin työntekijöillä voi olla tietoa ja osaamista jaettavaksi muiden kanssa. Yhteisöjen täysjäsenetkin oppivat jatkuvasti työtapojen muuttuessa. (Fuller ym. 2005.) Henkilöstövoimavarojen hallinnan näkökulmasta kysymys on paljolti siitä, miten ihmisiin, laitteisiin, toimintatapoihin ja organisaatiokulttuureihin varastoitunutta tietoa onnistutaan hyödyntämään prosessien ja organisaation tuloksen parantamiseksi.

Oppimista käytäntöyhteisöissä on tutkittu muun muassa havainnoimalla ja haastattelemalla yhteisöjen jäseniä ja jäseniksi oppivia. Käytäntöyhteisöä lähtökohtanaan hyödyntävien tutkimusten teemojen monipuolisuutta kuvaavat tutkimuskohteet, kuten tutkimuksen organisointi tutkimusryhmissä (Degn ym. 2018), yrittäjien sitoutuminen ja virtuaalinen ilmaisu (Hafeez ym. 2018), käytäntöyhteisöjen vaikutukset yksilön ja yhteisön kehitykselle organisaatioissa (Manuti ym. 2017) ja varhaiskasvatusjohtajien kokemukset käytäntöyhteisöstä (Ratner ym. 2018) sekä sukupuolentutkimukseen liittyen naisopettajien feministinen identifioituminen (McKnight 2018). Tällaiset oppimistutkimukset ovat suhteellisen hankalia toteuttaa. Prosessien empiirinen tutkimus vie runsaasti aikaa ja usein tutkimuksessa joudutaan käyttämään epäsuoria menetelmiä. Tutkimuskohteena eivät ole oppimistulokset, joita tyypillisesti tutkitaan testeillä, vaan oppiminen inter- ja intraindividuaalisina prosesseina (Schmitz 2006, 433). Oppimisen tavat ja tilanteet työpaikoilla ovat paitsi moninaisia (Fuller ym. 2005) usein vaikeasti havaittavia (Sheehan ym. 2017, 1056).

\section{METAFORAT OPPIMISTUTKIMUKSEN APUNA}

Käytäntöyhteisöissä (Lave \& Wenger 1991) oppimisen muodot ja tavat ovat moninaiset. Näkökulmassa korostuvat oppimiseen liittyvä tiedonkulku, pääsy oppimistilanteisiin ja mahdollisuus kartuttaa osaamista toisilta oppien. Tämän artikkelin empiirisen aineiston keruussa on sovellettu Anna Sfardin (1998) kehittämää jaottelua osallistumis- ja tiedonhankintametaforiin 
Taulukko 1. Oppimisen kolme metaforaa (Hakkarainen \& Paavola 2008 mukaillen)

\begin{tabular}{|c|c|c|c|}
\hline Metafora & Oppijan toiminnan kuvaus & Oppimisen kuvaus & Esimerkkejä \\
\hline Tiedonhankinta & $\begin{array}{l}\text { Ihminen subjektiivisena } \\
\text { yksilöllisenä toimijana. }\end{array}$ & $\begin{array}{l}\text { Oppiakseen ihminen tarvitsee } \\
\text { tietopohjaa ja tietorakenteita. } \\
\text { Mieleen rakentuu myös } \\
\text { toimintatapoja. Oppiminen } \\
\text { on mielensisäisen monologin } \\
\text { kaltaista. }\end{array}$ & $\begin{array}{l}\text { Alan kirjallisuuden ja } \\
\text { ammattijulkaisuiden } \\
\text { lukeminen, alan } \\
\text { koulutuksiin } \\
\text { osallistuminen }\end{array}$ \\
\hline Osallistuminen & $\begin{array}{l}\text { Ihminen } \\
\text { vuorovaikutussuhteessa } \\
\text { interindividuaalisena } \\
\text { toimijana. }\end{array}$ & $\begin{array}{l}\text { Ihminen oppii kanssakäymisessä } \\
\text { sosiaalisessa elämänpiirissä. } \\
\text { Oppiminen on kulttuuristen } \\
\text { käytäntöjen sisäistämistä. } \\
\text { Keskiössä ovat yhteisöt ja } \\
\text { kontekstiin sidottu toiminta. } \\
\text { Oppiminen on dialogista ja } \\
\text { vuorovaikutus korostuu. }\end{array}$ & $\begin{array}{l}\text { Työkokemuksista } \\
\text { keskustelu, avunanto ja } \\
\text { neuvonta työkavereiden } \\
\text { kesken, kokoukset, } \\
\text { joissa keskustelua ja } \\
\text { tiedon saantia työpaikan } \\
\text { asioista }\end{array}$ \\
\hline Tiedonluominen & $\begin{array}{l}\text { Ihminen } \\
\text { vuorovaikutussuhteessa } \\
\text { interindividuaalisena } \\
\text { toimijana, kohteellisuutta ja } \\
\text { objektisuuntautuneisuutta } \\
\text { korostaen. }\end{array}$ & $\begin{array}{l}\text { Ihmiset oppivat fokusoituessaan } \\
\text { yhteiseen kohteeseen. Keskeistä } \\
\text { on sekä uuden tiedon luominen } \\
\text { että yhteisöllisen prosessin } \\
\text { kehittäminen. }\end{array}$ & $\begin{array}{l}\text { Osallistuminen } \\
\text { työtapojen } \\
\text { kehittämiseen ja } \\
\text { yhteisten ohjeiden } \\
\text { laadintaan }\end{array}$ \\
\hline
\end{tabular}

sekä Paavolan ym. (2004) näihin lisäämään tiedonluomismetaforaan. Metaforia käytetään edustamaan kolmea työssä oppimisen muotoa, jotka ovat (1) oppiminen tietoa hankkimalla, (2) oppiminen osallistumalla ja (3) oppiminen uuden tiedon luomisena (ks. taulukko 1). Kuten Hakkarainen ja Paavola $(2008,60)$ toteavat, metaforat ovat heuristisia välineitä, jotka auttavat hahmottamaan oppimiseen ja yksilön kehittymiseen liittyviä perustavanlaatuisia prosesseja.

Pyrimme tässä tutkimuksessa oppimisen metaforien avulla hahmottamaan tiivistetysti olennaisia ja tyypillisiä työssä oppimisen muotoja ja niiden suosiota henkilöstön keskuudessa. Tiedonhankintametaforassa oppiminen on ensisijaisesti kognitiivinen, "mielensisäinen" prosessi, jossa oppimista tarkastellaan yksilöllisenä tietorakenteiden ja toimintamallien rakentumisena ihmisen mieleen (Hakkarainen \& Paavola 2008). Yksinkertaisia esimerkkejä tästä ovat salasanojen painaminen mieleen tai laulunsanojen opettelu ulkoa. Tiedonhankinnassa oppimisen eteneminen peruskäsitteiden omaksumisen jälkeen edellyttää laajentuvaa tietovarantoa rakenteineen. Esimerkiksi matematiikan oppimisessa ensin on hallittava alkeistaso, minkä jälkeen vasta voi edetä vaativampaan matemaattiseen ajatteluun. Tiedonhankinta-näkökulma on monille kaikkein perinteisin tapa ymmärtää oppimisprosessi. Kuten Hakkarainen ja Paavola $(2008,76)$ toteavat, tiedonhankintaan perustuva tieto on kiistatta ihmisen älykkään toiminnan peruskivi, mutta vain osa ihmisen taidoista nojaa määrätietoisesti hankittuun käsitteelliseen ja kielelliseen tietämykseen.

Osallistuva oppiminen puolestaan kuvaa oppimista kulttuuristen käytäntöjen omaksumisena sosiaalisessa kanssakäymisessä yhteisön muiden jäsenten kanssa. Yhteisöön sosiaalistumisessa on kuitenkin kyse muustakin kuin tietojen omaksumisesta. Prosessissa sopeudutaan työpaikan kulttuuriin, sen normeihin, arvoihin ja käytäntöihin. Prosessissa konkretisoituu yksilölle luonteva, tiedostamaton taipumus ajatella 
ja käyttäytyä määrätyllä tavalla tietyissä tilanteissa. Hyvä esimerkki on uuden työntekijän kehittyminen kokeneen ammattilaisen opissa: ajan kuluessa työntekijän kokemus karttuu, ja kokeneelta ammattilaiselta omaksuttu asiantuntijuus sulautuu osaksi uuden työntekijän ajattelu- ja toimintatapoja sekä mahdollisesti jopa kehonkieltä.

Tiedonluomisen metafora puolestaan viittaa oppimiseen pitkäjänteisenä ja systemaattisena yhteisen prosessin kehittämisenä, esimerkiksi yhteisöllisen toiminnan jatkuvana parantamisena. Keskeisessä asemassa on kollektiivinen tietämysverkko, mutta samalla osallistujien yksilöllinen toiminta on kriittisen tärkeässä roolissa. Tiedonluomisessa pyrkimyksenä on aiemman tietämyksen järjestelmällinen laajentaminen ja sosiaalisten käytäntöjen uudistaminen. (Hakkarainen \& Paavola 2008; Paavola ym. 2006; Paavola ym. 2004.) Tiedonluominen on osallistuvaa oppimista tietoisemmin päämäärähakuista toimintaa, jolla ryhmä yhdessä tavoittelee uudenlaisia ratkaisuja ongelmiin ja käytäntöihin.

Varmaankin lähes jokaisen työntekijän oppimisesta voidaan löytää kaikkien kolmen metaforan mukaista oppimista, mutta yhdellä osallistuva oppiminen on tyypillisintä, toisella taas tiedonhankinta ja kolmannella tiedonluominen. Oppimisen muoto riippuu paljolti työtehtävästä ja työkulttuurista. Mutta myös kunkin yksilön henkilöhistoria määrittää oppimista taipumusten ja valmiuksien kautta.

\section{SUKUPUOLI, IKÄ JA ASEMA OPPIMISMAHDOLLISUUKSIEN MÄÄRITTÄIINÄ}

Työelämän koulutustoiminnassa havaittavat säännönmukaisuudet kytkeytyvät niin rakenteellisiin tekijöihin kuin työntekijän ominaisuuksiin. Rakenteellisiin tekijöihin lukeutuvat muun muassa yrityskokoon, toimialaan, sijaintiin, omistajatyyppiin, ammattiin sekä organisaation hierarkiaan liittyvät säännönmukaisuudet (Asplund 2005; Barron ym. 1997; Bishop 1996). Myös yksilön ominaisuuksien, kuten sukupuolen, iän, työkokemuksen ja koulutuksen, on havaittu olevan yhteydessä siihen, kouluttaako työnantaja häntä ja kuinka paljon (Silvennoinen \& Lindberg 2016). Työntekijän iän, sukupuolen ja sosioekonomisen aseman yhteyttä työssä op- pimiseen on perusteltua katsoa kahdesta suunnasta. Ensiksi, organisaation suunnasta katsoen olennaista on se, millaisia koulutus-, oppimis- ja itsensä kehittämisen mahdollisuuksia eri asemat ja tehtävät tekijöilleen tarjoavat, ja miten eri-ikäiset miehet ja naiset on sijoiteltu erilaisiin tehtäviin. Toiseksi, yksilön suunnasta katsoen on tärkeää, millainen oppimis- ja koulutushistoria eri asemissa olevilla ja eri-ikäisillä miehillä ja naisilla on. Molempien näkökulmien ottaminen huomioon auttaa ymmärtämään henkilön suhtautumista koulutukseen ja oppimiseen sekä hänen itselleen sopivaksi kokemia oppimistapoja.

Vaikkakin rakenteelliset ja yksilöön liittyvät tekijät voidaan analyyttisesti erotella toisistaan, elävässä elämässä ne kietoutuvat toisiinsa. Esimerkiksi sukupuoli voidaan ymmärtää myös rakenteellisena tekijänä, koska ammatit ja koulutustutkinnot ovat vahvasti segregoituneet sukupuolen mukaan. Usein puhutaankin tämän vuoksi miesammateista ja naisammateista (esim. Jacobs 2003; Julkunen 2008, 155-162; Naumanen 2002, 62-65) sekä tasa-ammateista (Tilastokeskus 2016, 48-49). Suomessa ammattien segregaatio sukupuolen mukaan on poikkeuksellisen vahvaa (Ellingsaeter 2013, 507; Jarman ym. 2012, 1009; OECD 2002, 88-89). Se vaikuttaa myös siihen, miten ja mitä miehet ja naiset työelämässä oppivat. Tehtävät tämän tutkimuksen kohdeorganisaatioissa, vesihuoltolaitoksissa, ovat niin ikään jakautuneet sukupuolen mukaan.

Se, kuinka paljon työnantaja investoi eri henkilöstöryhmien kouluttamiseen ja oppimismahdollisuuksiin, on tietynlainen indikaatio myös työntekijän asemasta organisaatiossa. Yleensä koulutusta saavat eniten organisaation ydinhenkilöstöön lukeutuvat. Vähiten työnantaja investoi yksinkertaista rutiinityötä tekeviin (Eurofound 2002, 9-10) ja määräaikaisissa työsuhteissa oleviin sekä tilapäisiksi palkattuihin, niin kutsuttuun reunatyövoimaan (Kalleberg 2003, 158-164, 173; Kauhanen \& Nätti 2015, 789-790). Ydinhenkilöstöstä halutaan pitää kiinni myös muotoilemalla työtehtäviä kiinnostaviksi ja kehittäviksi sekä vastaamaan ammattitaidostaan huolehtivien toiveita (Boxall \& Macky 2009, 12-13, 17-18). Tällaisissa arvostetuissa tehtävissä uuden oppiminen ei tapahdu vain organisoidun koulutuksen kautta, vaan oppimis- ja kehittymismahdollisuuksia rakennetaan tietoisesti sisään työhön ja työyhteisön 
toimintatapoihin (esimerkiksi joustavat urakehitysmallit ja vertaismentorointi, kollegiaalisissa ryhmissä työskentely sekä mahdollisuus yksin työskentelyn ja ryhmätyöskentelyn vuorotteluun) (Meyer \& Evans 2005, 248-249, 251). Erityisesti nuoret ikäluokat edellyttävät työltä mielekkyyttä (Aapola-Kari \& Wrede-Jäntti 2017, 162-63; Järvinen 2003, 379; Myllyniemi 2017, 28). Niin ikään korkeasti koulutetut odottavat työltään sisällöllistä mielekkyyttä (Esser \& Lindh 2018, 151-152, 157) sekä mahdollisuutta itsensä kehittämiseen (Gallie ym. 2012, 818-819). Työntekijöiden yksilöllisiin kehitystarpeisiin vastaaminen näkyy osaltaan myös johtajuuden (Avolio ym. 2009; Lämsä ym. 2015, 207-208) ja työnorganisoinnin (Oinas ym. 2016, 680) uusissa aatteissa. Toisaalta taas, kuten inhimillisen pääoman teorian klassikot Gary Becker (1964) ja Jacob Mincer $(1962 ; 1989)$ ovat esittäneet, työnantajalla on vahva intressi pitää kiinni kokeneista ja työpaikalla paljon koulutusta ja oppia saaneista työntekijöistä. Heidän ei haluta siirtyvän käyttämään osaamistaan kilpailevien yritysten hyväksi.

Työelämän tutkimuksissa on tehty moninaisia tulkintoja iän yhteydestä työssä oppimiseen. Esimerkiksi vanhempiin työntekijöihin liitetyt negatiiviset stereotypiat voivat johtaa syrjintään työtehtäviin sijoittelussa, minkä seurauksena vanhemmille työntekijöille tarjotaan vähemmän tukea työssä oppimiseen. On myös tutkimusnäyttöä siitä, että kouluttautumista rajoittaa pikemmin työnantajan tarjoamien mahdollisuuksien puute kuin ikääntyvien työtekijöiden vähäinen kiinnostus tai välinpitämättömyys kouluttautumiseen (Taylor 2010, 263265). Varsinkin kokeneiden asiantuntijoiden on ikääntyessäänkin havaittu jatkavan oppimista ja hyödyntävän oppimismahdollisuuksia sekä työssä että työn ulkopuolella (Fuller \& Unwin 2006, 21, 37).

Kansainvälisesti vertaillen työnantajan järjestämällä koulutuksella on taipumus olla yksilön työuralla etupainotteista, vaikkakin Euroopan maiden välillä on huomattavan suurta vaihtelua. Suomessa ja Ruotsissa koulutukseen osallistuu noin puolet sekä nuorten että ikääntyneiden työntekijöiden ryhmissä, kun taas suuremmat maat, kuten Ranska, Saksa ja Italia, jäävät kauas pohjoismaisista osallistumisasteista (Taylor
2010, 263). Työolobarometrin aineistoilla tehdyn tutkimuksen mukaan Suomessa työnantajat kouluttavat eniten 35-45-vuotiaita työntekijöitä (Silvennoinen \& Nori 2012). Sen sijaan nuorten ja ikääntyneiden työntekijöiden osallistumisasteet ovat selvästi pienemmät kuin keski-ikäisten. Työssä oppimisen eri muotoihin liittyviä kokemuksia valottaa Kyndtin ym. (2009, 376-379) tutkimus, jossa nuorimmilla työntekijöillä näyttäisi olevan muita ikäryhmiä vähemmän mahdollisuuksia palautteen saantiin ja osaamisen kartuttamiseen. Vanhimmat työntekijät puolestaan kokivat muita ikäryhmiä useammin, että heillä on hyvät mahdollisuudet saada tietoa työpaikalla.

Kaiken kaikkiaan kehitysmahdollisuuksien jakautuminen näyttää olevan epätasaista huolimatta siitä, että kaikkien työntekijöiden odotetaan jatkuvasti kehittävän ammattitaitoaan. On vanhastaan tunnettua, että koulutusmahdollisuuksia hyödyntävät eniten ne, jotka ovat jo entuudestaan hankkineet runsaasti koulutusta ja pätevyyttä. Vähäinen koulutus osoittautui avaintekijäksi tutkimuksessa, jossa vanhemmat teollisuustyöntekijät (pääosin miehiä) pitivät itseään soveltumattomina uuden oppimiseen ja heiltä puuttui itseluottamus osallistua työpaikan ulkopuolisiin formaaleihin koulutuksiin (Warr \& Birdi 1998, 190). Ammateissa vallitsevat kulttuurit poikkeavat toisistaan, mikä näkyy myös eri ammattikuntiin lukeutuvien suhtautumisessa uuden oppimiseen ja koulutuskäytäntöihin (Harteis ym. 2015, 64, 68).

Tutkimustulokset tukevat käsitystä, että myös sukupuoli on yhtäältä yhteydessä organisaation tarjoamiin oppimismahdollisuuksiin ja toisaalta yksilön rohkeuteen tarttua erilaisiin tilaisuuksiin. Ikään liittyvät tutkimukset kertovat, että ikääntyneiden pääsy osalliseksi oppimistilanteisiin voi vaikeutua, vaikka halukkuutta oppimiseen yhä olisikin. Ja etenkin organisaatioasema näyttää vaikuttavan oppimistilanteisiin osalliseksi pääsyyn, mutta myös yksilön osallistumisaktiivisuuteen. Vain niukasti on saatavilla tutkittua tietoa siitä, millaiset työssä oppimisen muodot koetaan mieluisiksi ja miten eri taustatekijät ovat yhteydessä suosittuihin työssä oppimisen muotoihin. Tällä tutkimuksella pyritäänkin täyttämään tätä aukkoa ja paneudutaan kyselyaineiston avulla työssä oppimisen tapoihin. 


\section{TUTKIMUKSEN AINEISTO JA MENETELMÄT}

Tässä tutkimuksessa analysoidaan sukupuolen, iän ja organisaatioaseman yhteyttä työssä oppimisen tapoihin: millaiset oppimisen tavat eri-ikäiset miehet ja naiset organisaation eri tasoilla kokevat sopivimmiksi? Tutkimuksen kohderyhmänä ovat vesihuoltolaitosten työntekijät, jotka ovat perinteisesti hankkineet huomattavan osan osaamisestaan työssä oppimalla. Alan tutkinnot ovatkin näyttötutkintoja, joiden suorittaminen edellyttää työssä hankittua osaamista ja näytön antamista todellisissa työtilanteissa (Opetushallitus). Empiirinen aineisto kerättiin kyselylomakkeella, joka lähetettiin keväällä 2013 Vesilaitosyhdistyksen jäsenpostitusten jakelulistalla oleville laitosten yhteyshenkilöille $(\mathrm{N}=289)$. Käytännön toimintatavat vaihtelevat laitoksittain, joten yhteyshenkilöt ovat eri asemissa olevia henkilöitä, joiden työtehtävään kuuluu jäsenpostien käsittely ja tarvittaessa tiedon jakaminen niille, joita jäsenpostin aihepiiri kulloinkin koskee. Sähköpostilla lähetetyn kyselyn otsikossa kerrottiin, että viesti on tarkoitettu jakeluun koko henkilökunnalle. Viestissä pyydettiin jakamaan kyselyä koko henkilökunnalle ja kannustettiin kaikkia laitoksen työntekijöitä vastaamaan siihen. Vastauksia saatiin eri henkilöstöryhmistä $(\mathrm{N}=412)$ yhteensä 115 laitokselta. Laitostasolla vastaajat edustavat $40 \%$ Vesilaitosyhdistyksen jäsenlaitoksista. Alalle tyypillisesti vastaajien työpaikoista kaksikymmentä suurinta tarjoaa vesihuoltopalvelut noin puolelle Suomen asukkaista. Kun aineistoa verrataan Vesilaitosyhdistyksen jäsenistöön, vastauksia saatiin sekä alueellisesti että laitoskoon mukaan kattavasti. Kyselyn vastaajista valtaosa (96\%) on kunnan palveluksessa.

Väestörakenteen muutos tulee voimakkaasti vaikuttamaan työvoiman rakenteeseen myös Suomen vesihuoltolaitoksilla (Vesilaitosyhdistys 2013). Suomessa vesihuoltoalan merkittäväksi haasteeksi on tunnistettu henkilöstön osaamisen varmistaminen ja ylläpito. Ongelmaksi koetaan erityisesti henkilöstön eläköityminen ja hiljaisen tiedon katoaminen (Silfverberg 2017). Tutkittua tietoa vesihuoltosektorin työssä oppimisesta on kuitenkin vähän. Aikaisemman tutkimuksen (Hörkkö \& Silvennoinen 2017) perusteella tiedetään, että vesihuoltolaitosten henkilöstön kokema luottamus johtoon ja työkave- reihin on positiivisessa yhteydessä oppimisen sujuvuuteen työpaikalla. Tämän lisäksi on kuitenkin tärkeää tietää, millaiset oppimisen tavat ovat henkilöstön mielestä toimivia ja mieluisia.

Vesilaitosyhdistyksen $(2013,11)$ henkilöstöselvityksen ( $\mathrm{N}=151$ laitosta) mukaan $48 \%$ laitosten työntekijöistä oli syntynyt ennen vuotta 1960. Näin ollen lähes puolet laitosten henkilöstöstä saavuttaa eläkeiän vuoteen 2022 mennessä. Tähän tutkimukseen kerätyssä aineistossa vastaajien ikäjakauma (taulukko 2) on melko samanlainen muiden kuntatyöntekijöiden ikäjakauman kanssa (KT Kuntatyönantajat 2017). Henkilöstö vesihuoltolaitoksilla on miesvaltaista, mikä näkyy myös tässä aineistossa: 68 \% vastaajista on miehiä. Kyselyyn vastanneilla on jonkin verran matalampi koulutustaso kuin kuntaalalla työskentelevillä keskimäärin (KT Kuntatyönantajat 2017).

Aineiston työntekijät edustavat kolmea työtehtäväryhmää: (1) hallintohenkilöstöä, esimerkiksi toimitusjohtajat, kontrollerit ja toimistosihteerit, (2) teknistä henkilöstöä, esimerkiksi käyttöpäälliköt ja verkostoinsinöörit sekä (3) käyttöhenkilöstöä, esimerkiksi putkiasentajat ja kirvesmiehet. Tätä luokitusta käytettiin vastaajien organisaatioaseman määrittelyyn. Hallintohenkilöstöä edustaa kolmasosa vastaajista ja teknistä henkilöstöä hieman alle kolmasosa vastaajista. Käyttöhenkilöstöön kuului vastaajista reilu neljäkymmentä prosenttia. Luokittelun avulla muodostettiin kaksi luokkaa: työntekijät ja toimihenkilöt. Hallintohenkilöstö ja tekninen henkilöstö luokiteltiin toimihenkilöiksi ja käyttöhenkilöstö työntekijöiksi. Näin luokiteltuna noin $60 \%$ vastaajista on toimihenkilöitä ja $40 \%$ työntekijöitä. Miehiä on toimihenkilöistä reilu puolet ja työntekijöistä yhdeksän kymmenestä. Toimihenkilöillä on tyypillisesti opistotason tutkinto (lähes puolella). Työntekijöiden yleisin koulutus puolestaan on keskiasteen ammatillinen perustutkinto (kolmella neljästä). Vastaajien perustiedot on kuvattu taulukossa 2 .

Tilastollisten analyysien kannalta on hyvä, että vertailtavat ryhmät ovat kutakuinkin samansuuruiset. Kyselyyn vastanneet luokiteltiin syntymävuosikymmenen mukaan kolmeen luokkaan. Nuorin ikäryhmä on 1990-, 1980- ja 1970-luvuilla syntyneet, keskimmäinen ikäryhmä 1960-luvulla syntyneet, ja vanhin ikäryhmä 1950- ja 1940-luvuilla syntyneet. Näin nuorim- 
Taulukko 2. Kyselyyn vastanneiden koulutusaste ja ikä aseman ja sukupuolen mukaan (\%)

\begin{tabular}{lrrrrr}
\hline Koulutus & $\begin{array}{r}\text { Toimihenkilöt } \\
\mathrm{n}=239\end{array}$ & $\begin{array}{r}\text { Työntekijät } \\
\mathrm{n}=173\end{array}$ & $\begin{array}{r}\text { Naiset } \\
\mathrm{n}=132\end{array}$ & $\begin{array}{r}\text { Miehet } \\
\mathrm{n}=280\end{array}$ & $\begin{array}{r}\text { Kaikki } \\
\mathrm{N}=412\end{array}$ \\
\hline Ei ammattitutkintoa & 2 & 11 & 3 & 7 & 6 \\
Ammatillinen perustutkinto & 12 & 74 & 21 & 46 & 38 \\
Opistotason tutkinto & 46 & 10 & 46 & 24 & 31 \\
Alempi korkeakoulututkinto & 22 & 4 & 12 & 15 & 14 \\
Ylempi korkeakoulututkinto & 18 & 1 & 18 & 8 & 11 \\
Yhteensä & 100 & 100 & 100 & 100 & 100 \\
\hline Ikäryhmä & Toimihenkilöt & Työntekijät & Naiset & Miehet & Kaikki \\
& $\mathrm{n}=239$ & $\mathrm{n}=173$ & $\mathrm{n}=132$ & $\mathrm{n}=280$ & $\mathrm{~N}=412$ \\
\hline Ikä alle 43 & 33 & 36 & 31 & 36 & 34 \\
Ikä 43-53 & 26 & 37 & 32 & 30 & 31 \\
Ikä yli 53 & 41 & 26 & 37 & 34 & 35 \\
Yhteensä & 100 & 100 & 100 & 100 & 100 \\
\hline
\end{tabular}

mat olivat aineiston keruuvuonna alle 43-vuotiaita, keskimmäinen ikäluokka 43-53-vuotiaita ja vanhimmat yli 53-vuotiaita.

Vesihuoltolaitoksissa tehtävät ja asemat ovat jakautuneet sukupuolen mukaan, ja esimerkiksi eri ikäisten koulutustaustat poikkeavat selvästi toisistaan. Kaikilla näillä tekijöillä on todettu olevan vaikutusta koulutusasenteisiin ja oppimiseen. Tässä artikkelissa tutkitaan regressioanalyysilla sukupuolen, iän ja organisaatioaseman yhteyttä työntekijän suosimiin, oppimismetaforien mukaisiin työssä oppimisen muotoihin.

\section{TULOKSET}

Vastaajien näkemyksiä suosimistaan työssä oppimisen muodoista mitattiin kahdellatoista väittämälauseella, jotka oli muotoiltu teorian (Hakkarainen \& Paavola 2008) pohjalta. Lomakkeessa kysyttiin: mikä on sinulle sopiva tapa kartuttaa työssä tarvittavaa osaamistasi? Erilaisia oppimistapoja kuvaavista väittämälauseista pyydettiin valitsemaan itselleen soveliaat ja luontevat. Kaikki väittämät olivat Likert-asteikollisia, asteikko kuvasi vastauksia välillä 1 (täysin epäsopiva) - 5 (täysin sopiva). Väittämistä muodostettiin kolmea oppimisen metaforaa edustavat summamuuttujat: (a) tiedonhankinta, (b) osallistuva oppiminen ja (c) tiedonluominen (taulukko 3). Ensimmäinen, tiedonhankintaa oppimismuotona ilmentävä summamuuttuja koostuu neljästä väittämälauseesta, osallistuvaa oppi- mismuotoa kuvaava viidestä ja tiedonluomista oppimismuotona kuvaava summamuuttuja kolmesta väittämälauseesta. Summamuuttujien reliabiliteetit olivat riittävän hyviä (Cronbachin alfat $0,5-0,7)$.

Taulukossa 4 tarkastellaan täysin sopivana eri oppimismuotoja pitävien osuuksia sukupuolen, ikäryhmän ja organisaatioaseman mukaan ryhmäerojen tilastolliset merkitsevyydet huomioiden.

Yksittäisten väittämien kohdalla huomio kiinnittyy erityisesti organisaatioaseman mukaisiin suuriin eroihin (taulukko 4). Työntekijöitä useammin toimihenkilöt pitivät itselleen täysin sopivana lähes kaikkia tiedonhankintaa oppimismuotona ilmentäviä väittämiä, kuten esimerkiksi alan kirjallisuuden ja ammattijulkaisuiden lukemista sekä alan koulutukseen, kursseille ja seminaareihin osallistumista. Myös tiedonluomista oppimismuotona kuvaavia väittämiä toimihenkilöt pitivät itselleen täysin sopivana useammin kuin työntekijät. Tiedonluomista ilmensi esimerkiksi työyhteisön kehittämiseen osallistuminen.

Naiset suhtautuvat miehiä myönteisemmin kaikkiin oppimismuotoihin. Sukupuolten väliset erot olivat suurimmat tiedonhankinnassa ja osallistuvassa oppimisessa (taulukko 4). Yksittäisistä väittämistä nousee esille osaamisen kehittymistä edistävät keskustelut työkavereiden kanssa, minkä osalta sukupuolten välinen ero oli tilastollisesti erittäin merkitsevä. 
Taulukko 3. Oppimisen metaforat (Hakkarainen \& Paavola 2008) summamuuttujina

\begin{tabular}{|c|c|c|c|c|c|c|}
\hline Summamuuttuja & $\begin{array}{l}\text { Cronbachin } \\
\text { alfa }\end{array}$ & $\begin{array}{c}\text { Osioiden } \\
\text { korrelaatiot } \\
\text { summa- } \\
\text { muuttujaan }\end{array}$ & Summa & ittujan & Vinous & Huipukkuus \\
\hline Tiedonhankinta & 0,5 & & 3,8 & 0,5 & $-0,2$ & 0,1 \\
\hline $\begin{array}{l}\text { Alan kirjallisuuden ja ammattijul- } \\
\text { kaisuiden lukeminen. }\end{array}$ & & 0,4 & & & & \\
\hline $\begin{array}{l}\text { Ratkaisun selvittäminen } \\
\text { itsekseni kokeilemalla. }\end{array}$ & & 0,3 & & & & \\
\hline $\begin{array}{l}\text { Onnistumisten ja virheiden } \\
\text { itsenäinen pohdinta. }\end{array}$ & & 0,3 & & & & \\
\hline $\begin{array}{l}\text { Alan koulutukseen, kursseille ja } \\
\text { seminaareihin osallistuminen. }\end{array}$ & & 0,3 & & & & \\
\hline Osallistuva oppiminen & 0,6 & & 3,9 & 0,5 & $-0,4$ & 0,1 \\
\hline Työn tekeminen yhdessä. & & 0,3 & & & & \\
\hline $\begin{array}{l}\text { Keskustelu oman esimiehen } \\
\text { kanssa. }\end{array}$ & & 0,4 & & & & \\
\hline $\begin{array}{l}\text { Työkavereiden kanssa keskustelu, } \\
\text { jossa osaamiseni kehittyy. }\end{array}$ & & 0,5 & & & & \\
\hline $\begin{array}{l}\text { Toisen sijaisena ja tuuraajana } \\
\text { toimiminen. }\end{array}$ & & 0,3 & & & & \\
\hline $\begin{array}{l}\text { Toisten vesihuoltolaitosten } \\
\text { työntekijöiden tapaaminen. }\end{array}$ & & 0,3 & & & & \\
\hline Tiedonluominen & 0,7 & & 4,0 & 0,6 & $-0,5$ & 0,6 \\
\hline $\begin{array}{l}\text { Tuotteen tai palvelun tai työn } \\
\text { kehittämiseen osallistuminen. }\end{array}$ & & 0,5 & & & & \\
\hline $\begin{array}{l}\text { Laitoksen työtapojen kehittä- } \\
\text { miseen tai yhteisten ohjeiden } \\
\text { laadintaan osallistuminen. }\end{array}$ & & 0,6 & & & & \\
\hline $\begin{array}{l}\text { Työyhteisöni kehittämiseen } \\
\text { osallistuminen. }\end{array}$ & & 0,6 & & & & \\
\hline
\end{tabular}

Ikäryhmien vertailussa nuorimman ja vanhimman ikäryhmän kokemukset erosivat selkeimmin toisistaan varsinkin osallistuvaa oppimismuotoa kuvaavissa väittämissä (taulukko 4). Systemaattisia eroja ikäryhmien välillä ei prosenttijakaumien vertailussa kuitenkaan noussut esille.

Aineistossa kenellekään ei ollut täysin vierasta oppimismuoto, jossa hyödynnetään osallistuvaa oppimista, kuten keskusteluja tai työskentelyä yhdessä kollegoiden kanssa. Niin ikään suosittuna oppimistapana pidetään kehittämiseen osallistumista. Kyselyn perusteella vähemmän suosiossa näyttäisi olevan alan kirjallisuuden ja ammattijulkaisuiden lukeminen. Se muistuttaakin ehkä eniten perinteistä opiskelua tai kouluoppimista.

Kunkin työssä oppimisen muodon mieluisuutta selitetään taulukon 5 regressioanalyysissä sukupuolen, iän ja organisaatioaseman avulla. Tässä aineistossa tiedonhankkimista ja tiedonluomista selittää ainoastaan yksi tekijä - organisaatioasema. Sen sijaan osallistuvaa oppimista selittää sekä sukupuoli että ikä. Mallin selitysasteet jäävät kuitenkin mataliksi. 


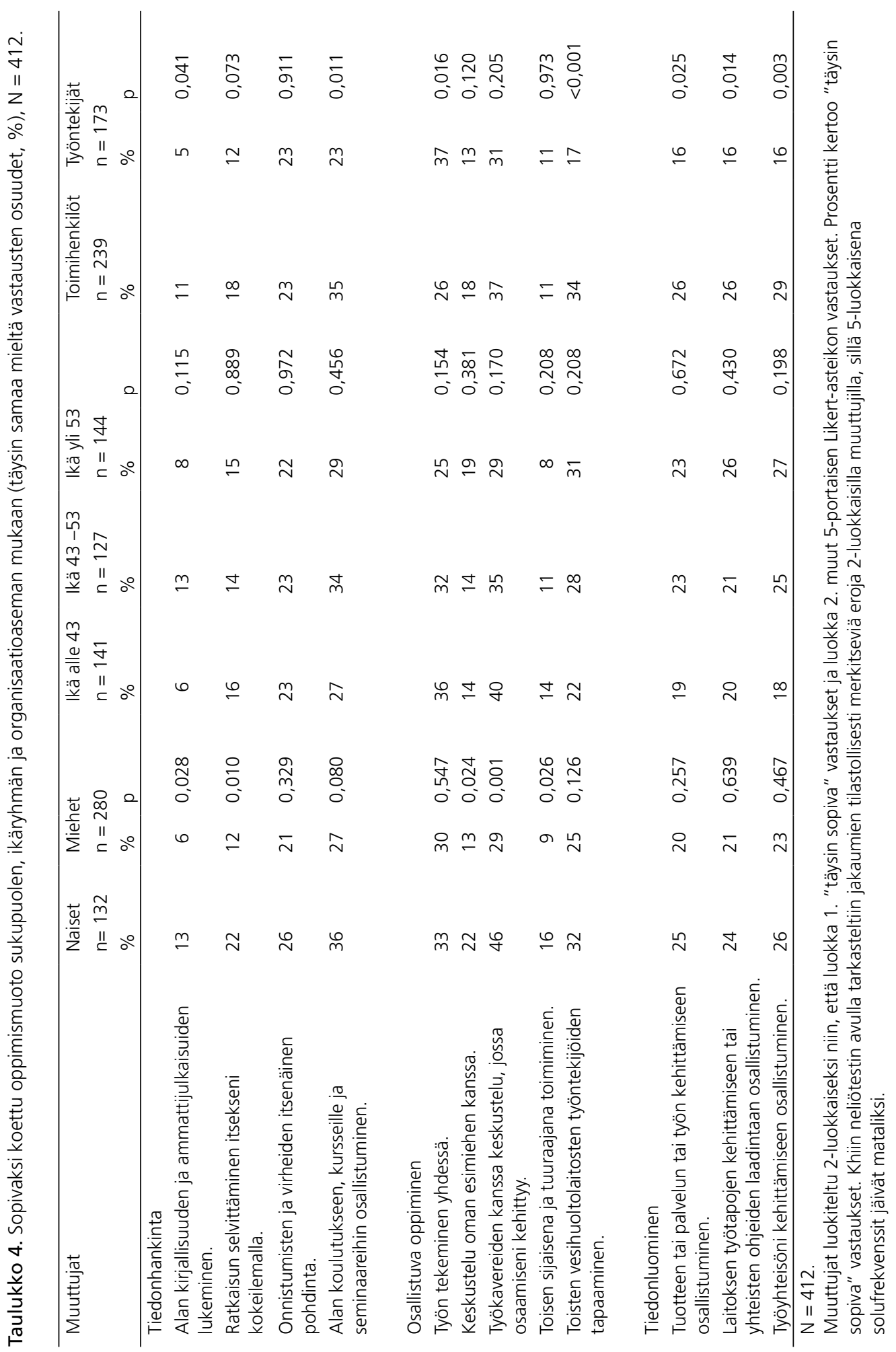


Taulukko 5. Regressioanalyysit sukupuolen, iän ja organisaatioaseman yhteydestä eri oppimismuotoihin (vain tilastolliset merkitsevät tulokset esitetty taulukossa)

\begin{tabular}{|c|c|c|c|c|c|c|c|c|}
\hline $\begin{array}{l}\text { Sopiva } \\
\text { oppimistyyli } \\
\text { eli selitettävä } \\
\text { muuttuja }\end{array}$ & $\begin{array}{l}\text { Selittävä } \\
\text { muuttuja }\end{array}$ & $\begin{array}{l}\beta, \\
\text { (stand- } \\
\text { ardized } \\
\text { coeffi- } \\
\text { cients) }\end{array}$ & $\mathrm{t}$ & $\begin{array}{l}\text { P, regres- } \\
\text { sioker- } \\
\text { toimen } \\
\text { merkitse- } \\
\text { vyys }\end{array}$ & $\begin{array}{l}\mathrm{R}^{2} \text {, mallin } \\
\text { selitys- } \\
\text { aste }\end{array}$ & $\begin{array}{l}\text { P, selitys- } \\
\text { asteen } \\
\text { merkit- } \\
\text { sevyys, } \\
\text { (anova) }\end{array}$ & $\begin{array}{l}\text { Selitysas- } \\
\text { teen efek- } \\
\text { tikoon } \\
\text { tulkinta } \\
\text { Cohenin } \\
(1988) \\
\end{array}$ & $\begin{array}{l}\mathrm{N}, \text { kun } \\
\text { outlierit } \\
\text { poistettu }\end{array}$ \\
\hline $\begin{array}{l}\text { Tiedon- } \\
\text { hankkiminen }\end{array}$ & $\begin{array}{l}\text { Organisaatio- } \\
\text { asema, jossa } \\
\text { toimihenkilö = } 1 \text {, } \\
\text { työntekijä }=0\end{array}$ & 0,18 & 3,67 & $<0,001$ & 0,03 & $<0,001$ & pieni & 411 \\
\hline \multirow[t]{2}{*}{$\begin{array}{l}\text { Osallistuva } \\
\text { oppiminen }\end{array}$} & $\begin{array}{l}\text { Sukupuoli, jossa } \\
\text { nainen }=1 \\
\text { mies }=0\end{array}$ & 0,17 & 3,44 & 0,001 & & & & \\
\hline & $\begin{array}{l}\text { lkä, jossa alle } \\
43 \text {-vuotaiaat }=1 \\
\text { muut }=0\end{array}$ & 0,11 & 2,29 & 0,023 & 0,04 & $<0,001$ & pieni & 411 \\
\hline $\begin{array}{l}\text { Tiedon- } \\
\text { luominen }\end{array}$ & $\begin{array}{l}\text { Organisaatio- } \\
\text { asema, jossa } \\
\text { toimihenkilö = } 1, \\
\text { työntekijä = } 0\end{array}$ & 0,17 & 3,56 & $<0,001$ & 0,03 & $<0,001$ & pieni & 409 \\
\hline
\end{tabular}

Askeltava (stepwise) muuttujien valintamenetelmä.

\section{LOPUKSI}

Suomen koulutuspolitiikassa on viime vuosikymmeninä toteutettu toimenpiteitä koulutuksen kytkemiseksi lähemmäs työelämää. Perusteluissa on vedottu ammattien ja työtehtävien taitovaatimuksien nopeaan muuttumiseen. Toisaalta ammatillista koulutusta on kritisoitu liiallisesta koulumaisuudesta, minkä lisäksi pääosin oppilaitoksissa tapahtuvan koulutuksen on katsottu olevan kallis tapa ammattitaitojen hankkimiseksi. Meneillään oleva ammatillisen koulutuksen kokonaisuudistus siirtääkin oppimista entistä enemmän työpaikoille. Samalla tieto siitä, millaiset oppimisen tavat ovat henkilöstön mielestä toimivia ja mieluisia, on tullut entistä tärkeämmäksi. Osaamisen kehittäminen ja koulutus- ja oppimismahdollisuuksien tarjoaminen työntekijöille ovat entistä tärkeämpi osa yritysten ja julkisorganisaatioiden henkilöstöhallintoa. Työntekijät pitävät kehittymismahdollisuuksia yhtenä hyvän työn ominaisuutena.
Tässä artikkelissa on tutkittu henkilöstön itselleen sopivaksi kokemia työssä oppimisen muotoja. Empiirisenä aineistona oli vesihuoltolaitosten henkilöstölle tehty kysely. Tutkimuksen kohteena oli sukupuolen, iän ja organisaatioaseman yhteys sopiviksi koettuihin työssä oppimisen muotoihin. On tietysti hyvä muistaa, etteivät naiset tai miehet muodosta yhtenäistä joukkoa sen enempää kuin kronologisen iän mukaan muodostetut ikäryhmätkään. Jo aiempien tutkimusten perusteella tiedämme, että esimerkiksi työntekijätehtävissä toimivien ikämiesten oppimistyyli ja koulutusasenteet voivat poiketa paljonkin korkeasti koulutettujen, toimihenkilöasemissa toimivien nuorten miesten tyyleistä ja asenteista.

Artikkelin lähtökohdaksi otettu käsitys oppimisesta perustuu teorioihin sosiaalisesta oppimisesta (Bandura 1977; 1997) ja käytäntöyhteisöistä (Lave \& Wenger 1991): yksilö oppii osallistuessaan työskentelyyn yhteisössä. Oppimistapoja luotaavan mittariston rakentamisessa 
ja tulkinnassa käytettiin Anna Sfardin (1998) kehittämiä osallistumis- ja tiedonhankintametaforia sekä Paavolan ym. (2006) niihin lisäämää tiedonluomismetaforaa.

Tulokset tukevat aiempaa tutkimusta siinä, että niin rakeenteelliset tekijät (Asplund 2005; Barron ym. 1997; Bishop 1996) kuin työntekijän ominaisuudet (Silvennoinen \& Lindberg 2016) kytkeytyvät läheisesti työelämässä tarjoutuviin oppimismahdollisuuksiin ja koulutuspreferensseihin. Tämän tutkimuksen lopputulemana tiedonhankinnan ja tiedonluomisen suosioon on yhteydessä organisaatioasema, kun taas osallistuvan oppimismuodon suosioon ovat yhteydessä sukupuoli ja ikä.

Organisaatioasema selvästikin vaikuttaa siihen, miten sopivaksi yksilö kokee tiedonhankintaoppimismuodon ja tiedonluomismuodon. Organisaatiohierarkiassa ylempänä olevat suosivat näitä oppimismuotoja useammin kuin työntekijäasemissa olevat. Tulos tukee muun muassa Cincinnaton ym. (2016) tutkimuksessa esitettyä ajatusta, jonka mukaan luokka-asemalla on yhteys yksilön sopiviksi kokemiin oppimismuotoihin. Tutkimuksissa on niin ikään todettu organisaatioaseman määrittävän paljolti yksilön kokemuksia työssä oppimisesta (Fuller \& Unwin 2006; Illeris 2006; Kyndt ym. 2009).

Toimihenkilöt kokevat työntekijöitä useammin tiedonhankinnan itselleen sopivaksi oppimismuodoksi. Se on tyypillisesti kognitiivista, propositionaaliseen tietoon perustuvaa oppimista, kuten alan kirjallisuuden ja ammattijulkaisuiden lukemista. Koulutusvaatimusten lisäksi tyypillinen toimihenkilötyö eroaa luonteeltaan työntekijätason tehtävistä. Myös tilanteet, joissa korostuu tiedonluominen oppimismuotona, voivat olla käytäntöineen ja puhetapoineen toimihenkilöille tutumpia kuin työntekijöille.

Kuten useissa tutkimuksissa on havaittu, aikaisemmat koulutuskokemukset vaikuttavat henkilön käsityksiin kouluttautumisesta ja oppimisesta. Toimihenkilöillä on työntekijöitä runsaammin koulutusta takanaan, joten heidän suhtautumistapansa koulutukseen ja oppimiseen voi kaiken kaikkiaan olla myönteisempi. Vähemmän koulutusta hankkineet voivat kokea muodollisesti organisoidut oppimistilanteet itselleen vieraaksi, ja heillä voi olla kielteisesti värittyneitä kokemuksia liittyen kouluun tai ulkoapäin organisoituun oppimiseen yleensä
(Illeris 2006, 6; Kyndt ym. 2009, 191).

Tulosten mukaan osallistuvan oppimismuodon suosioon puolestaan vaikuttavat sukupuoli ja ikä. Naiset pitivät kaikkia oppimismuotoja, mutta erityisesti osallistuvaa oppimismuotoa miehiä useammin itselleen sopivana. Osallistuvan oppimismuodon suosio antaa aihetta olettaa, että naiset kokevat asiantuntijuuden kehittymisen, paitsi mahdolliseksi, myös tavoittelemisen arvoiseksi työyhteisössään.

Nuorin ikäryhmä (alle 43-vuotiaat) suosii osallistuvaa oppimismuotoa useammin kuin vanhin ikäryhmä (yli 53-vuotiaat). Osallistuvan oppimismuodon suosion voi tulkita indikoivan, että nuorimmat työntekijät katsovat voivansa osallistuvan oppimisen kautta parhaiten kasvattaa omaa asiantuntijuuttaan vesihuoltolaitoksella. Näyttää siis siltä, että henkilöstön uudet jäsenet ideoineen pyrkivät mukaan keskusteluun ja siten osallisiksi käytäntöyhteisöön. Heidän kauttaan työyhteisöllä on mahdollisuus uudistumiseen. Usein uudet ideat ja innovaatiot saavat alkunsa käytäntöyhteisön rajanylityksissä (Farnsworth ym. 2016). Esimerkiksi työyhteisön uusi tulokas voi olla hankkinut arvokasta kokemusta kokonaan toisella alalla, mutta hänen asiantuntemustaan ei osata tunnistaa tai haluta tunnustaa vastaanottavassa yhteisössä. Pahimmillaan raja noviisin ja kokeneiden välillä estää kehitystä ja luo kokonaisuuden kannalta toimintaa hankaloittavaa "ryhmäajattelua". Kuten tavoitteellisissa ihmisyhteisöissä yleensäkin, käytäntöyhteisöissä valtaresurssit ja vallankäyttö ovat tärkeä toimintaa ja jäsenyyttä määrittävä tekijä.

Käytäntöyhteisössä valta näyttäytyy yhteisössä arvostetun osaamisen määrittelyssä ja asiantuntijuuden tunnustamisessa (Farnsworth ym. 2016). Sukupuoli- ja sukupolvierot voivat osoittautua esteeksi joidenkin henkilöstöryhmien suosimien oppimismahdollisuuksien organisoimiseksi. Tunnettua on, että vesihuoltolaitoksilla on miesvaltainen johto ja esimiehet. Lisäksi laitosjohtajista kaksi kolmasosaa on syntynyt 1940ja 1950-luvulla (Vesilaitosyhdistys 2013, 11). Vastakkainasettelua voi syntyä tiivistä osallistumista haluavien tulokkaiden ja syrjäytymistä pelkäävien sekä osallistumisen säätelemistä yrittävien vanhojen työntekijöiden välille (Billett 2004, 318; Lave \& Wenger 1991, 116). 
Vaikkakin tiedonhankintaan perustuva tieto on epäilemättä ihmisen rationaalisen ajattelun edellytys (Hakkarainen ja Paavola 2008, 76), vain osa ihmisen taidoista perustuu määrätietoisesti hankittuun käsitteelliseen ja kielelliseen tietämykseen. Käytäntöyhteisön sekä sen jäsenten osaamisen ja asiantuntijuuden kehittymiselle ensisijaisen tärkeää on johdon osoittama tuki sosiaalisen oppimisen moninaisille käytännöille. Myös uudistusten omaksumiseen liittyviä tiedonhallinnan ongelmia tutkinut Jalonen (2013) rohkaisee hyödyntämään osallistavia menetelmiä toimintatapojen kehittämisessä ja käyttöönotossa. Johto voi tietoisesti kannustaa asiantuntijuuden syventämiseen ja uudistumiseen.

Vesihuoltoala, jonka henkilöstö oli tutkimuksen kohteena, on vuosisatojen saatossa kehit-

\section{LÄHTEET}

Aapola-Kari, S. \& Wrede-Jäntti, M. (2017). Perinteisiä toiveita, nykyhetkeen kiinnittyviä pelkoja - nuoret pohtivat tulevaisuutta. Teoksessa Myllyniemi, S. (toim.) Katse tulevaisuudessa: Nuorisobarometri 2016 (s. 159175). Helsinki: Opetus- ja kulttuuriministeriö. http://urn.fi/URN:NBN:fi-fe201704045951

Asplund, R. (2004). The provision and effects of company training: A brief review of the literature, ETLA Discussion Papers. Helsinki: The Research Institute of the Finnish Economy. http://hdl.handle.net/10419/63988

Avolio, B.J., Walumbwa, F.O. \& Weber, T.J. (2009). Leadership: current theories, research, and future directions. Annual Review of Psychology, 60(2009), 421-449. doi: 10.1146/annurev. psych.60.110707.163621.

http://digitalcommons.unl.edu/cgi/viewcontent . cgi article $=1036 \&$ context $=$ management facpub

Bandura, A. (1977). Social Learning Theory. Oxford: Prentice-Hall.

Bandura, A. (1997). Self-efficacy: the exercise of control. New York: W.H. Freeman.

Barron, J., Berger, M. \& Black, D. (1999). Do Workers Pay for On-The-Job Training? The Journal of Human Resources, 34(2), 235-252. http://www.jstor.org/stable/146344

Becker, G. S. (1964). Human capital. A theoretical and empirical analysis with special reference to education. Chicago: University of Chicago Press.

Billett, S. (2004). Workplace participatory prac- tynyt kohtuullisen maltillisesti. Tänä päivänä myös vesihuoltoalaan vaikuttavat entistä voimakkaammin monet globaalit muutokset, kuten teknologian nopea kehitys tai ilmastonmuutoksen vuoksi lisääntyvät sään ääri-ilmiöt eli kuivuuskaudet ja tulvat (Silfverberg 2017). Tilanteen haasteellisuutta lisää se, että päättyvällä vuosikymmenellä suurehko osa vesihuoltolaitosten henkilöstöstä on saavuttanut eläkeiän (Vesilaitosyhdistys 2013). Onkin tärkeää, että työyhteisöt onnistuvat tarjoamaan henkilökunnalle mahdollisuuden osallistua ja kantaa vastuuta yhteisössä, jotta he voivat kokea osallisuutensa työyhteisössä merkitykselliseksi. Sitä kautta kehittyy entistä autonomisemmin omasta osaamisestaan huolehtiva henkilöstö.

tices. Conceptualising workplaces as learning environments. Journal of Workplace Learning, 16(6), 312-324.

http://dx.doi.org/10.1108/13665620410550295

Bishop, J. H. (1996). What we know about employer-provided training: A review of literature (CAHRS Working Paper \#96-09). Ithaca, NY: Cornell University.

https://digitalcommons.ilr.cornell.edu/cahrswp/180/

Boud, D \& Lee, A. (2005). Peer learning' as pedagogic discourse for research education, Studies in Higher Education, 30(5), 501-516.

https://doi.org/10.1080/03075070500249138

Boud, D. \& Middleton, H. (2003). Learning from others at work: communities of practice and informal learning. Journal of Workplace Learning, 15(5), 194-202.

https://doi.org/10.1108/13665620310483895

Boxall, P. \& Macky, K. (2009). Research and theory on high-performance work systems: progressing the high involvement stream. Human Resource Management Journal, 19(1), 3-23. https://doi.org/10.1111/j.17488583.2008.00082.x

Cedefop (2015). Unequal access to job-related learning: evidence from the adult education survey. Luxembourg: Publications Office. http://dx.doi.org/10.2801/219228

Cincinnato, S., De Wever, B., Van Keer, H. \& Valcke, M. (2016). The influence of social background on participation in adult education: applying 
the cultural capital framework. Adult Education Quarterly, 66(2), 143-168. https://doi.org/10.1177/0741713615626714

Degn, L., Franssen, T., Sørensen, M.P. \& de Rijcke, S. (2018). Research groups as communities of practice-a case study of four high-performing research groups. High Education, 76(231), 231-246. https://doi.org/10.1007/s10734-017-0205-2

Ellingsaeter, A. L. (2013). Scandinavian welfare states and gender (de) segregation: Recent trends and processes. Economic and Industrial Democracy, 34(3), 501-518. https://doi.org/10.1177/0143831X13491616

Engeström, Y. (2001). Expansive learning at work: Toward an activity theoretical reconceptualization, Journal of Education and Work, 14(1), 133-156.

https://doi.org/10.1080/13639080020028747

Esser, I. \& Lindh, A. (2018). Job preferences in comparative perspective 1989-2015: A multidimensional evaluation of individual and contextual influences. International Journal of Sociology, 48(2), 142-169.

https://doi.org/10.1080/00207659.2018.144611 8

Eurofound (2002). Quality of work and employment in Europe, issues and challenges. Luxembourg: Office for Official Publications of the European Communities. Luettu 13.9.2018 https://bit.ly/2NaNTSc

Eurostat (2018). Labour market and lifelong learning. Adult Education Survey. Participation rate in education and training by occupation 2007-2016. Luettu 20.7.2018 http://appsso.eurostat.ec.europa.eu/nui/show.do?dataset=trng aes_104\&lang=en

Fenwick, T. (2010). Trends in workplace learning research. Adult education - as a field of study. International Encyclopedia of Education (Third Edition), 83-88. Elsevier.

http://dx.doi.org/10.1016/B978-0-08-0448947.00012-9

Fuller, A., Hodkinson, H., Hodkinson, P. \& Unwin, L. (2005). Learning as peripheral participation in communities of practice: a reassessment of key concepts in workplace learning. British Educational Research, 31(1), 49-68. https://doi.org/10.1080/0141192052000310029

Fuller, A. \& Unwin, L. (2006). Older and wiser? Workplace learning from the perspective of experienced employees. International Journal of Lifelong Education, 24(1), 21-39.

http://dx.doi.org/10.1080/026037042000317329

Farnsworth, V., Kleanthous, I. \& Wenger-Trayner,
E. (2016). Communities of practice as a social theory of learning: a conversation with Etienne Wenger. British Journal of Educational Studies, 64(2), 139-160.

https://doi.org/10.1080/00071005.2015.1133799

Gallie, D., Felstead, A. \& Green, F. (2012). Job preferences and the Intrinsic quality of work. Work, Employment and Society, 26(5), 806-821. https://doi.org/10.1177/0950017012451633

Hafeez, K., Foroudi, P., Nguyen, B., Gupta, S. \& Alghatas, F. (2018). How do entrepreneurs learn and engage in an online community-of-practice? A case study approach. Behaviour and Information Technology, 37(7), 714-735. https://doi.org/10.1080/0144929X.2018.1474255

Hakkarainen, K. (2000). Oppiminen osallistumisen prosessina. Aikuiskasvatus, 20(2), 84-98. http://urn.fi/URN:NBN:fi:ELE-536851

Hakkarainen, K. \& Paavola, S. (2008). Asiantuntijuuden kehittyminen, hiljainen tieto ja uutta luovat tietokäytännöt. Teoksessa Toom, A., Onnismaa, J. \& Kajanto, A. (toim.) Hiljainen tieto, tietämistä, toimimista, taitavuutta (s. 59-82). Aikuiskasvatuksen 47. vuosikirja. Helsinki: Gummerus.

Harteis, C., Billett, S., Goller, M., Rausch, A. \& Seifried, J. (2015). Effects of age, gender and occupation on perceived workplace learning support. International Journal of Training Research, 13(1), 64-81. http://dx.doi.org/10.1080/14480220.2015.1051 349

Hörkkö, E. \& Silvennoinen, H. (2017). Sukupuolen ja organisaatioaseman yhteys työssä oppimiseen ja luottamukseen - tarkastelussa vesihuoltolaitosten henkilöstö. Kunnallistieteellinen aikakauskirja 45(1), 7-26. http://urn.fi/URN:NBN:fi:ELE-1819302

Illeris, K. (2006). Lifelong learning and the lowskilled. International Journal of Lifelong Education, 25(1), 15-28. https://doi.org/10.1080/02601370500309451

Jacobs, J. A. (2003). Detours on the Road to Equality: Women, Work and Higher Education. Contexts, 2(1), 32-41.

https://doi.org/10.1525/ctx.2003.2.1.32

Jalonen, H. (2013). Systeemisen innovaation omaksumisen tiedonhallinnalliset haasteet. Hallinnon tutkimus, 32(2), 95-112.

http://urn.fi/URN:NBN:fi:ELE-1618426

Jarman, J., Blackburn, R.M., Racko, G. (2012). The dimensions of occupational gender segregation in industrial countries. Sociology, 46(6), 10031019. https://doi.org/10.1177/0038038511435063 
Julkunen, R. (2008). Uuden työn paradoksit. Keskusteluja 2000-luvun työprosess(e)ista. Tampere: Vastapaino.

Järvinen, T. (2003). Erikoislukiolaisten käsityksiä työnteosta. Kasvatus: Suomen kasvatustieteellinen aikakauskirja, 34(4), 374-389. http://urn.fi/URN:NBN:fi:ELE-1381034

Kalleberg, A. L. (2003). Flexible firms and labor market segmentation: Effects of workplace restructuring on jobs and workers. Work and Occupations, 30(2), 154-175.

https://doi.org/10.1177/0730888403251683

Kauhanen, M. \& Nätti, J. (2015). Involuntary temporary and part-time work, job quality and well-being at work. Social Indicators Research, 120(3), 783-799. https://doi.org/10.1007/s11205-014-0617-7

KT Kuntatyönantajat (2017). Tilastot ja julkaisut. Luettu 6.10.2018 https://www.kt.fi/tilastot-ja-julkaisut/henkilostotilastot

Kyndt, E., Dochy, F. \& Nijs, H. (2009). Learning conditions for non-formal and informal workplace learning. Journal of Workplace Learning, 21(5), 369-383.

http://dx.doi.org/10.1108/13665620910966785

Lave, J. \& Wenger, E. (1991). Situated learning: Legitimate peripheral participation. New York: Cambridge University Press.

Lyly-Yrjänäinen, M. (2018). Työolobarometri 2017 Ennakkotiedot. Työ- ja elinkeinoministeriö. http://urn.fi/URN:ISBN:987-952-327-293-4

Lämsä, A.M., Keränen, A. \& Savela, T. (2015). Vastuullinen johtajuus esimies-alaissuhteessa. Hallinnon tutkimus, 34(3), 205-218. http://www.doria.fi/handle/10024/142891

Manuti, A., Impedovo, M.A. \& De Palma, P.D. (2017). Managing social and human capital in organizations: Communities of practices as strategic tools for individual and organizational development. Journal of Workplace Learning, 29(3), 217-234.

https://doi.org/10.1108/JWL-07-2016-0062

McKnight, L. (2018). A bit of a dirty word: 'feminism' and female teachers identifying as feminist. Journal of Gender Studies, 27(2), 220-230. https://doi.org/10.1080/09589236.2016.1202816

Meyer, L.M. \& Evans, I.M. (2005). Supporting academic staff: Meeting new expectations in higher education without compromising traditional faculty values. Higher Education Policy, 18(3), 243-255.

https://doi.org/10.1057/palgrave.hep.8300086

Mincer, J. (1962). On the job training: Cost, returns, and implications. Journal of Political Economy, 70(2), 50-79. http://dx.doi.org/10.1086/258725

Mincer, J. (1989). Human capital and the labor mar- ket: A review of current research. Educational Researcher, 18(4), 27-34.

https://doi.org/10.3102/0013189X018004027

Murphy, R. (1988). Social Closure. Oxford: Clarendon Press.

Myllyniemi, S. (toim.) (2017). Katse tulevaisuudessa. Nuorisobarometri 2016. Nuorisoasiain neuvottelukunnan julkaisuja nro 56. Helsinki. https:// tietoanuorista.fi/wp-content/uploads/2017/03/ Nuorisobarometri_2016_WEB.pdf

Naumanen, P. (1994). Tiedon, taidon ja vallan tiellä. Koulutussosiologian tutkimuskeskuksen raportti 22. Turku: Turun yliopisto.

Naumanen, P. (2002). Koulutuksella kilpailukykyä: koulutuksen yhteys miesten ja naisten työllisyyteen ja työn sisältöön. Koulutussosiologian tutkimuskeskuksen raportti 57. Turku: Turun yliopisto.

Oinas, T., Anttila, T. \& Mustosmäki, A. (2016). Työn organisoinnin muutos yksityisellä ja julkisella sektorilla. Lisääntyvätkö uudet työn organisoinnin muodot Pohjoismaissa? Yhteiskuntapolitiikka, 81(6), 670-680. http://urn.fi/URN:NBN:fi-fe2016121431441

OECD (2002). Employment Outlook. Women at work: who are they and how are they faring? http://www.oecd.org/employment/ emp/17652667.pdf

OECD (2005). Promoting Adult Learning. Participation in adult learning: the figures and the problems. Paris: OECD Publishing. http:// dx.doi.org/10.1787/9789264010932-en

OECD (2013). OECD skills Outlook 2013. First results from the survey of adult skills. Paris: OECD Publishing.

OECD (2017). Indicator C6 How many adults participate in education and learning?, in Education at a Glance 2017. Paris: OECD Publishing. https://doi.org/10.1787/eag-2017-28-en

Opetushallitus. Ammatillinen koulutus. Luettu 7.10.2018 https://www.oph.fi/saadokset_ja_ohjeet/opetussuunnitelmien_ja_tutkintojen_perusteet/ammatillinen_koulutus

Paavola, S., Hakkarainen, K. \& Seitamaa-Hakkarainen, P. (2006). Tutkivan oppimisen periaatteita ja käytäntöjä: "trialoginen" tiedonluomisen malli. Teoksessa Järvelä, S., Häkkinen, P. \& Lehtinen, E. (toim.) Oppimisen teoria ja teknologian opetuskäyttö (s. 147-180). Helsinki: WSOY.

Paavola, S., Lipponen, L. \& Hakkarainen, K. (2004). Models of innovative knowledge communities and three metaphors of learning. Review of Educational Research, 74(4), 557-576. doi:https://doi.org/10.3102/00346543074004557. 
Ratner, H.H., Bocknek, E.L., Miller, A.G., Elliott, S.L. \& Weathington, B. (2018). Creating communities: a consortium model for early childhood leaders. Teacher Development, 22(3), 427-446. https://doi.org/10.1080/13664530.2017.1367718

Rinne, R., Silvennoinen, H. \& Valanta, J. (1995). Työelämän aikuiskoulutus: valta, vastuu ja intressit henkilöstökoulutuksessa. Koulutussosiologian tutkimuskeskuksen raportti 29. Turku: Turun yliopisto.

Roscigno, V.J., Mong, S., Byron, R. \& Tester, G. (2001). Age discrimination, social closure and employment. Social Forces, 86(1), 313-334. https://doi.org/10.1353/sof.2007.0109

Sfard, A. (1998). On two metaphors for learning and dangers of choosing just one. Educational Researcher, 27(2), 4-13. https://doi.org/10.3102/0013189X027002004

Sheehan, D., Jowsey, T., Parwaiz, M., Birch, M., Seaton, P., Shaw, S., Duggan A. \& Wilkinson T. (2017). Clinical learning environments: place, artefacts and rhythm. Medical Education, 51(10), 1049-1060.

https://doi.org/10.1111/medu.13390

Silfverberg, P. (2017). Vesihuollon suuntaviivat 2020-luvulle. Helsinki: Vesilaitosyhdistys. https://valtioneuvosto.fi/documents/ 1410837/1516651/

Vesihuollon+suuntaviivat+2020-luvulle_final_ 20170622.pdf/cb687a80-dd57-4733-88c7f3962e4bf9f4

Silvennoinen, H. \& Lindberg M. (2016). Työelämän koulutuksen jakautuminen ja tasa-arvo. Teoksessa Silvennoinen, H., Kalalahti, K. \& Varjo, J. (toim.) Koulutuksen tasa-arvon muuttuvat merkitykset (s. 321-347). Jyväskylä: Suomen kasvatustieteellinen seura.
Silvennoinen, H. \& Nori, H. (2012). Ikääntyvien koulutus monimuotoistuvassa työelämässä. $A i$ kuiskasvatus, 32(3), 177-189. http://urn.fi/URN:NBN:fi:ELE-1547275

Schmitz, B. (2006). Advantages of studying processes in educational research. Learning and Instruction, 16(5), 433-449. https://doi.org/10.1016/j.learninstruc.2006.09.004

Taylor, P. (2010). Age equality in education and training. International Encyclopedia of Education (Third Edition), 262-268. Elsevier. http://researchonline.federation.edu.au/vital/ access/HandleResolver/1959.17/75251

Tilastokeskus (2016). Naiset ja miehet Suomessa 2016. Luettu 15.8.2018 http://www.stat.fi/tup/ julkaisut/tiedostot/julkaisuluettelo/yyti_namisu_201600_2016_16132_net_p4.pdf

Vesilaitosyhdistys (2013). Vesihuoltolaitosten henkilöstöselvitys 2011. Helsinki: Vesilaitosyhdistys.

Vygotsky, L. S. (1978). Mind in society: The development of higher psychological processes. London: Harvard University Press.

Väyrynen, H., Helander, N. \& Jalonen, H. (2015). Tietämyksenhallinta osana organisaation toimintaa: hallintaa vai hämmennystä? Hallinnon Tutkimus, 34(4), 310-325. http://urn.fi/URN:NBN:fi:ELE-1776228

Warr, P. \& Birdi, K. (1998). Employee age and voluntary development activity. International Journal of Training and Development, 2(3), 190204. https://doi.org/10.1111/1468-2419.00047

Wenger, E. (1998). Communities of Practice: Learning, Meaning, and Identity. New York: Cambridge University Press.

Wertsch, J.V. (2010). Vygotsky and Recent Developments. International Encyclopedia of Education (Third Edition), 231-236. Elsevier. https://doi-org.ezproxy.utu.fi/10.1016/B978-008-044894-7.00490-5 